\title{
World Journal on Educational Technology
}

\section{Professional development of teachers in the context of the lifelong learning model: The role of modern technologies}

Larisa Abdalina a*, Department of Pedagogy and Pedagogical Psychology, Voronezh State University, Univesitetskaya square, 1, Voronezh, 394018, Russian Federation https://orcid.org/0000-0002-0414$\underline{2263}$

Elena Bulatova ${ }^{b}$, Novovoronezh Polytechnic College, Branch of the National Research Nuclear University MEPhl (Moscow Engineering Physics Institute), Oktyabrskaya str., 1, Novovoronezh, 396073, Russian Federation https://orcid.org/0000-0002-9294-381X

Snezhana Gosteva ' , Department of Social-Humanitarian, Natural-Scientific and General Professional Disciplines, Rostov State University of Railway Transport, Revolyutsii str., 31a, Voronezh, 394030, Russian Federation https://orcid.org/0000-0001-7367-2543

Ludmila Kunakovskaya d, Department of Pedagogy and Pedagogical Psychology, Voronezh State University, Univesitetskaya square, 1, Voronezh, 394018, Russian Federation https://orcid.org/0000-0002-1345$\underline{8462}$

Olesya Frolova e, Secondary School No. 54, Okruzhnaya str., 3, Voronezh, 394002, Russian Federation https://orcid.org/0000-0001-5533-5439

\section{Suggested Citation:}

Abdalina, L., Bulatova, E., Gosteva, S., Kunakovskaya, L., \& Frolova, O. (2022). Professional development of teachers in the context of the lifelong learning model: The role of modern technologies. World Journal on Educational Technology. 14(1), 117-134. https://doi.org/10.18844/wjet.v14i1.6643

Received from October 04, 2021; revised from October 22, 2021; accepted from November 28, 2021. Selection and peer review under responsibility of Prof. Dr. Servet Bayram, Yeditepe University, Turkey. (C)2022 Birlesik Dunya Yenilik Arastirma ve Yayincilik Merkezi. All rights reserved.

\begin{abstract}
The relevance of this research is due to the need to study the possibilities of lifelong learning in modern educational settings. Its central aim was to consider the influence of modern technologies on the level of professionalism of teachers in the process of lifelong learning. For this, a specially developed model aimed at increasing student motivation was introduced, and corresponding pre- and post-surveys were conducted. The results of the experiment showed an increase in the demand for lifelong learning in the modern learning environment and the active use of modern technologies. In the meantime, the outcomes of the repeated survey demonstrated the expansion of the list of motivation factors. Prospects for further research are seen in the possibility of applying the results obtained when analyzing the features of lifelong learning in other countries in the context of the modern education system in a comparative aspect. Apart from this, future studies use the achieved findings to scrutinize the influence of pedagogical innovations on lifelong learning effectiveness.
\end{abstract}

Keywords: Education system, lifelong learning, modern technologies, pedagogical innovation,; professionalism.

* AdDRESS FOR CORRESPONDENCE: Larisa Abdalina, Department of Pedagogy and Pedagogical Psychology, Voronezh State University, Univesitetskaya square, 1, Voronezh, 394018, Russian Federation

E-mail address: labdalina@rambler.ru / Tel.: +89036504390 


\section{Introduction}

The modern education system requires the development of new methodological approaches and the use of modern technologies in the learning process. Thus, in pedagogy, a bigger number of opportunities for the use of pedagogical innovations aimed at improving the professionalism of the teacher, increasing the motivation of students to acquire knowledge, and forming a new teaching model of a practical nature is being created. Among the leading approaches of today is a personalityoriented one formed on the principles of humanization and democratization of the educational process in relation to the personality of a student or teacher (Yakubova, 2021). At Russian universities, there is a growing demand for lifelong learning, which contributes to the professional development of teachers and is identified as one of the promising areas for future development of education (Bazarova et al., 2018). Studies conducted on the basis of the analysis of the education systems of Hong Kong and Finland have shown that one of the factors affecting the professional development of educators is their continuous development (Gracheva et al., 2020). Due to the fact that lifelong learning is defined as a process of acquiring and improving knowledge throughout life, it implies continuous professional advancement, upgrading already acquired skills, and gaining new ones in the study process. This methodological approach provides learners with the opportunity to be open and ready to receive new relevant information that appears every day owing to the rapid development of all spheres of life. At the same time, lifelong learning contributes not only to professional advancement but also personal one as it improves mental abilities, critical thinking, and memory, increases the level of self-confidence, and arouses a desire for knowledge and study, allowing a person to acquire the ability to adapt to new things quickly (Keating, 2020).

An educational approach of a practical nature that is based on pedagogical innovations and modern technologies is especially relevant in pandemic conditions. The era of technical development and the invention of new technologies encourages educators to revise traditional educational approaches and elaborate new teaching methods involving pedagogical innovations (Avidov-Ungara \& Forkosh-Baruch, 2018). The influence that modern technologies exert on the effectiveness of lifelong learning is particularly relevant and useful during the global pandemic and lockdown, like the one associated with the COVID-19 infection. The last two years have shown that the availability of a large number of various educational programs and blogs, video services, personal knowledge managers, courses, and workshops made it possible to learn and gain new knowledge with no limitations (Kimmons, 2018). Apart from this, researchers declare that the use of modern technologies in the learning process raises students' learning motivation as they get the opportunity not only to study theory but also to master professional skills in practice, express themselves, and develop creativity, critical thinking, and readiness for further professional activities (Berestova et al., 2021). In view of the foregoing, revision and update of curricula and programs in order to include modern technologies in the process of students' training is a promising area for further work (Safari \& Noori, 2019).

\subsection{Literature Review}

The concept "professional development of teachers" is described as the improvement of the educators' competencies, knowledge, skills, and abilities that they use or will use in professional activity. Continuing professional development gives teachers the opportunity to acquire new skills or improve those they possess. The effectiveness of lifelong learning has been proved in the context of various specialties and models of modern education. For example, American researchers have concluded that lifelong learning is effective in learning English as a second language highlighting the need for this methodological approach not only in foreign language learning but also in developing 
practical critical thinking skills and cultural competence of a person (Ho \& Coady, 2018). Scholars from Brazil have proved the positive impact of lifelong learning on teaching, which is manifested primarily in the willingness to learn throughout life, invest in one's own development, develop in pedagogy and related disciplines, improve knowledge about teaching approaches, as well as be open to new methodological strategies and adapt to the peculiarities of their implementation (De Oliveira Menezes et al., 2021).

In the process of lifelong learning, such professional qualities of a teacher as self-identification, selfactualization, and self-realization are developed. This occurs due to constant search for new teaching methods, use of modern technological tools, and implementation of pedagogical innovations promoting teachers' professional development (Burkhanova et al., 2020). An analysis of the Canadian higher education system showed that pedagogical innovations have an impact on improving the quality of education and increasing professionalism while giving students the opportunity to access courses and programs remotely (Walder, 2017). In addition, pedagogical innovations allow one to expand methodological strategies when working with students, organically combine theory with practice, and use modern approaches to education (Christopher et al., 2017).

Portuguese researchers, based on modern educational approaches such as a focus on practice and development of students' creativity, critical thinking, readiness for group work, and improvement of communication skills, have identified such pedagogical innovations as differentiated learning, collaboration, problem-based and problem-solving learning, role play, blended learning, and flipped classroom (Carvalho et al., 2021). In this context, the issue of teacher cooperation and the exchange of experience directly related to the use of pedagogical innovations when working with students is critically important. An example of the development of such pedagogical and research direction is a methodology developed in Denmark, which aims to develop a center as a learning environment with video support to allow teachers to work in teams and engage in the creation of innovative educational projects for students (Weitze, 2017).

Modern technologies in lifelong learning are one of the ways to improve the effectiveness of the overall process of education, develop reflective, creative, and critical thinking, enhance students' motivation and interest in learning, as well as make them ready to apply the knowledge gained in practice (Khudoykulov et al., 2019). These include various learning networks, open educational resources, and mobile and contextual learning means, which help improve the level of lifelong learning and avoid difficulties in the process of its practical implementation (Kalz, 2014). At the same time, mobile technologies, as elements popular with young people, provide an opportunity to combine theory and information with interactive teaching methods that allow each student to work individually or in a team by discussing completed assignments or accepted creative ideas (Rakhmatov, 2021). Modern approaches to learning also presuppose the application of other interactive teaching approaches, such as the " $3 \times 4$ " method, the "Blitz game" method, the "Interview" technique, the "Hierarchy" technique, or even the use of special lifelong learning-programmed robots. All of them aim to develop students' abilities to think independently and logically (Salakhova \& Shamsitdinova, 2020; Romero et al., 2020).

Distance learning (the use of various information technologies through a means of communication on the Internet) has gained particular popularity in recent years as one of the most effective ways for lifelong learning implementation. This inference can be traced throughout the work of many scholars. For instance, while scrutinizing Islamic education, researchers from Indonesia came to the conclusion that in the current pandemic context, innovative technologies for remote learning have become 
increasingly common and are actively used in pedagogy (Mardiana \& Supriyatno, 2020). In the modern digital world, it is possible to use special training programs, video lessons, lectures, conduct hands-on classes in specially equipped classrooms and laboratories (Shoaxmedova \& Mannanova, 2020). Technological advancements have become ubiquitous, which allows their active use of online platforms, websites, virtual libraries, online encyclopedias, various audiovisual aids, and overhead projectors in lifelong learning (Jălu, 2019).

Experimental data obtained based on the responses of individuals from seven European countries such as Bulgaria, Czech Republic, Germany, Greece, Norway, Poland, and Great Britain show that unemployment and early job insecurity are the factors motivating young people to continue their learning (Ilieva-Trichkova \& Boyadjieva, 2020). Conditions such as difficulties in finding a job or the inability to find a decent job encourage students to make a decision to continue their studies for the sake of professional skills improvement. Researchers declare that the first reason for introducing a lifelong learning model into the education system is the lack of well-trained educators, particularly of a young age (Nagovitsyn et al., 2019). The second reason lies in the impact of digitalization on students, on the basis of which opportunities for socialization and building a new model of student-teacher relationship are expanded (Zanina et al., 2019). In general, the evidence from the literature suggests the prospects and the opportunity for self-realization and achievement of success are the core factors motivating students to engage in lifelong learning (Vasilyeva et al., 2019).

Despite the abundance of studies on the matter, their key problem resides in poor attention given to the issue of the relationship between lifelong learning, professional development of teachers, and pedagogical innovations. Their impact on improving professionalism in the learning process, as well as the level of the development of lifelong learning with the use of latest technologies in the universities and main factors of motivation for students to continue their studies, require more thorough examination.

\subsection{Problem Statement}

The very aim of this study was to gain new experimental data that will allow investigating the role of modern technologies in the process of lifelong learning and describing their influence on the professional development of teachers in the current system of education. Its achievement presupposed the accomplishment of the following research objectives:

- $\quad$ analyze the features of the development of a lifelong learning model based on the data obtained from the experiment conducted in several higher education institutions;

- reveal the effect of lifelong learning on the professional development of future teachers;

- trace the role of modern technologies in lifelong learning and determine the level of their implementation in the educational process in the selected institutions, as well as their impact on lifelong learning effectiveness.

\section{Methods and Materials}

\subsection{Research Design and Sample}

The study was carried out at Voronezh State University, Novovoronezh Polytechnic College (a branch of the National Research Nuclear University MEPhI (Moscow Engineering Physics Institute)), Rostov State Transport University. The experiment involved 658 technical students of the 1-4 year of 
study. Such a sample composition intended to analyze the attitudes towards lifelong learning and the use of modern technologies of students of the 1st, 2nd, and 3rd study years (who could change their general opinions on education) and 4th-year students (who were about to decide whether to continue pedagogical studies to obtain a master's degree and had a formed opinion concerning the need for lifelong learning). Another important goal this selection followed was to track the effect of the process of studying in different years on students' stances towards education and desire or unwillingness to continue learning. The study took place from April to May 2021.

\subsection{Survey}

The experiment was conducted in three stages. At the first stage, the study authors developed a special survey consisting of the following 7 questions (no additional materials were used): "Is there is a need for lifelong learning in the modern education system?", "Does lifelong learning affect an increase in professionalism?", "What is the level of the development of lifelong learning in your educational institution?", "Do you consider lifelong learning?", "What is your motivation to continue learning?", "Are modern technologies used in your educational institution?", "What is the effect of modern technologies on the process of lifelong learning?". All of them were gathered in one Google form sent to respondents via e-mail. The questionnaire had no time limit for answering. After its fulfillment, all the answers were sent for further processing.

At the second stage, enrolled students were trained according to the developed program aimed at increasing their motivation for lifelong learning. The training course duration was one month.

At the third stage, a repeated survey was conducted to determine the level of students' motivation for lifelong learning and the impact of the developed program on its state. Special attention here was paid to the questions "Do you consider lifelong learning?", "What is your motivation for lifelong learning?". The survey procedure was the same as that used during the first research stage.

\subsection{Research Limitations}

The limitations of the study are associated with a small sample as the experiment was conducted in three technical universities (Voronezh State University, Novovoronezh Polytechnic College (a branch of the National Research Nuclear University MEPhI (Moscow Engineering Physics Institute)), Rostov State Transport University) and did not take into account data from other universities located in different countries.

\subsection{Ethical Issues}

The survey was anonymous; there was no need to provide confidential information (name, surname, age or place of residence, etc.). The only requirement was to indicate the study year at the time of the experiment. The investigation was carried out in compliance with ethical standards, and all respondents gave written consent to process the data obtained in the course of the study.

\section{Results}

The collected survey outcomes enabled a thorough analysis of the features of the development of the lifelong learning model, of the degree to which new technological solutions are used in educational institutions, and of the opinions of students concerning the very lifelong learning concept and its necessity. Correspondingly, students' assessments and observations were critical here. More details on the survey results are presented in Figures 1-7. 
As is evidenced in Figure 1, the majority of students (91\%) noted that there is a need for lifelong learning these days, which indicates a desire for self-development and professional skills improvement. However, $9 \%$ have an opposite opinion, which means a preference for traditional views on education and teaching methods that are not in line with modern educational needs.

\section{Is there is a need for lifelong learning in the modern education system?}

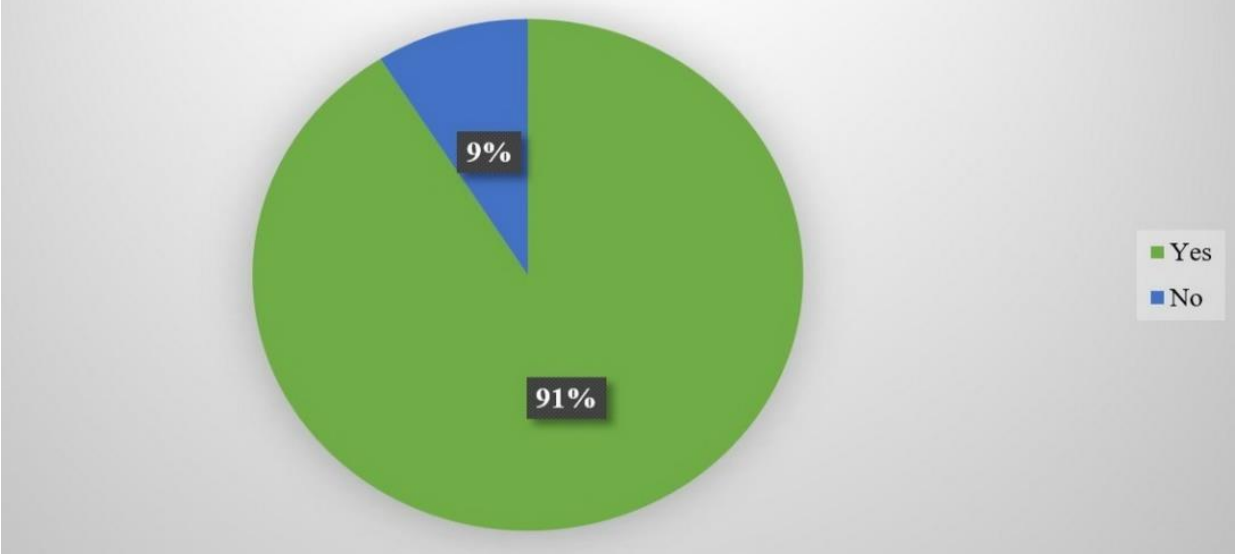

Figure 1. Respondents' answers to the question "Is there a need for lifelong learning in the modern education system?"

Figure 2 shows respondents' answers to the question "Does lifelong learning affect an increase in professionalism?" Thus, according to the results obtained, $95 \%$ of students are confident that in the process of lifelong learning, there is an increase in professionalism as, together with self-education, it contributes to the assimilation and application of new knowledge and professional skills. At the same time, $5 \%$ believe that lifelong learning does not affect an increase in professionalism, which may mean a lack of awareness of modern methodological approaches in education or the belief in the advantages of the traditional education system.

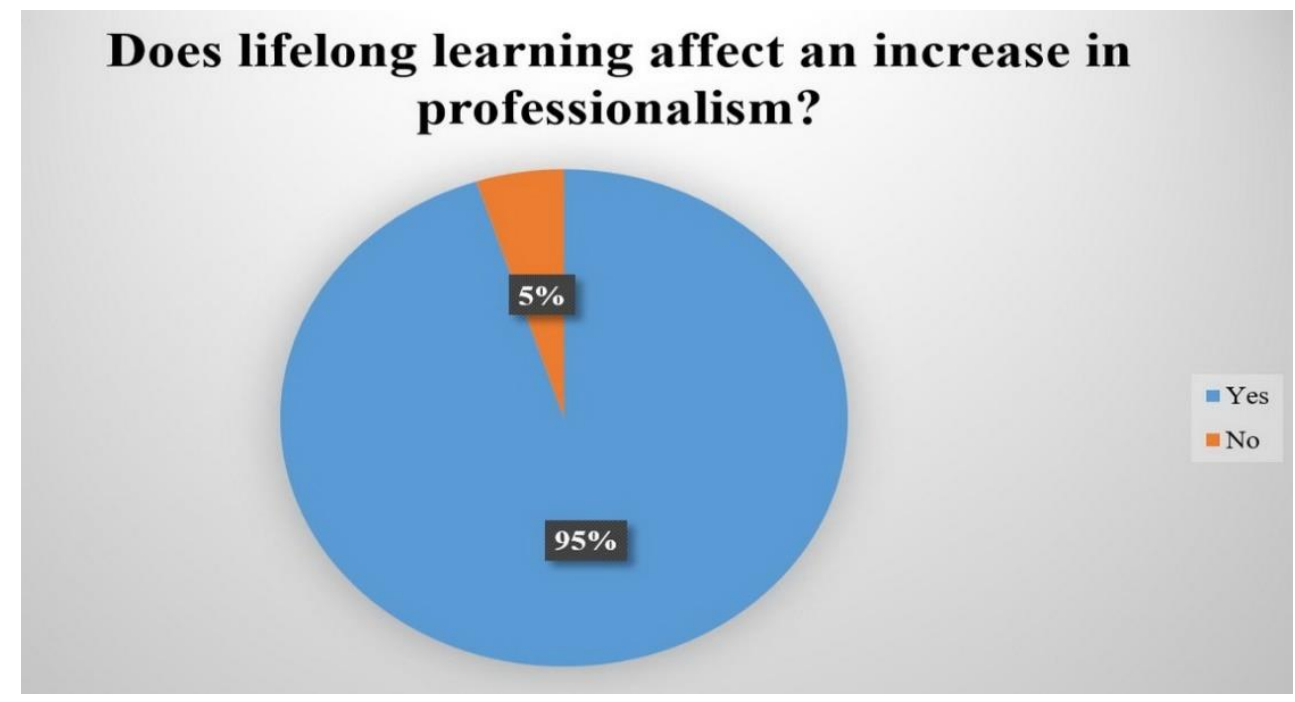

Figure 2. Respondents' answers to the question "Does lifelong learning affect an increase in professionalism?" 
Data presented in Figure 3 provide respondents' answers to the question "What is the level of the development of lifelong learning in your educational institution?" The collected indicators show that $70 \%$ of students believe that lifelong learning in their educational institution is well-developed. However, $20 \%$ are convinced of the average level of the development of lifelong learning, and $10 \%$ assess it as low.

\section{What is the level of the development of lifelong learning in your educational institution?}

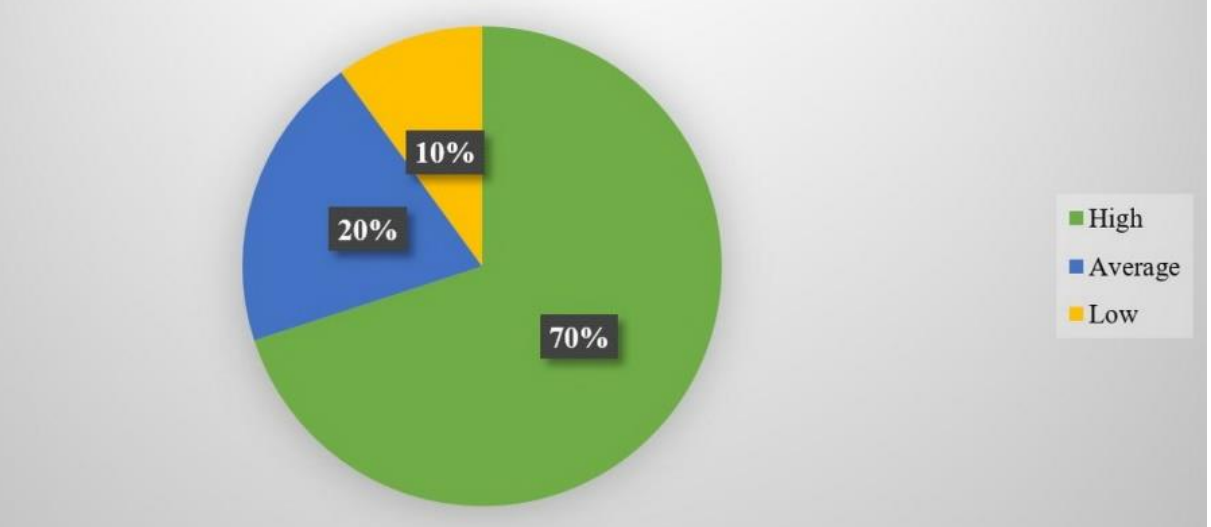

Figure 3. Respondents' answers to the question "What is the level of the development of lifelong learning in your educational institution?".

The previous data may somehow explain research participants' responses to the question "Do you consider lifelong learning?" (Figure 4). In general, the shares of students' answers were distributed as follows: $45 \%$ of respondents plan to continue lifelong learning, $25 \%$ are likely to continue, $10 \%$ have not decided yet, $15 \%$ are unlikely to continue learning, and 5\% noted that they do not consider lifelong learning at all. These data indicate that the majority of students (70\%) not only support the need for lifelong learning these days but also plan to gain such experience themselves. 


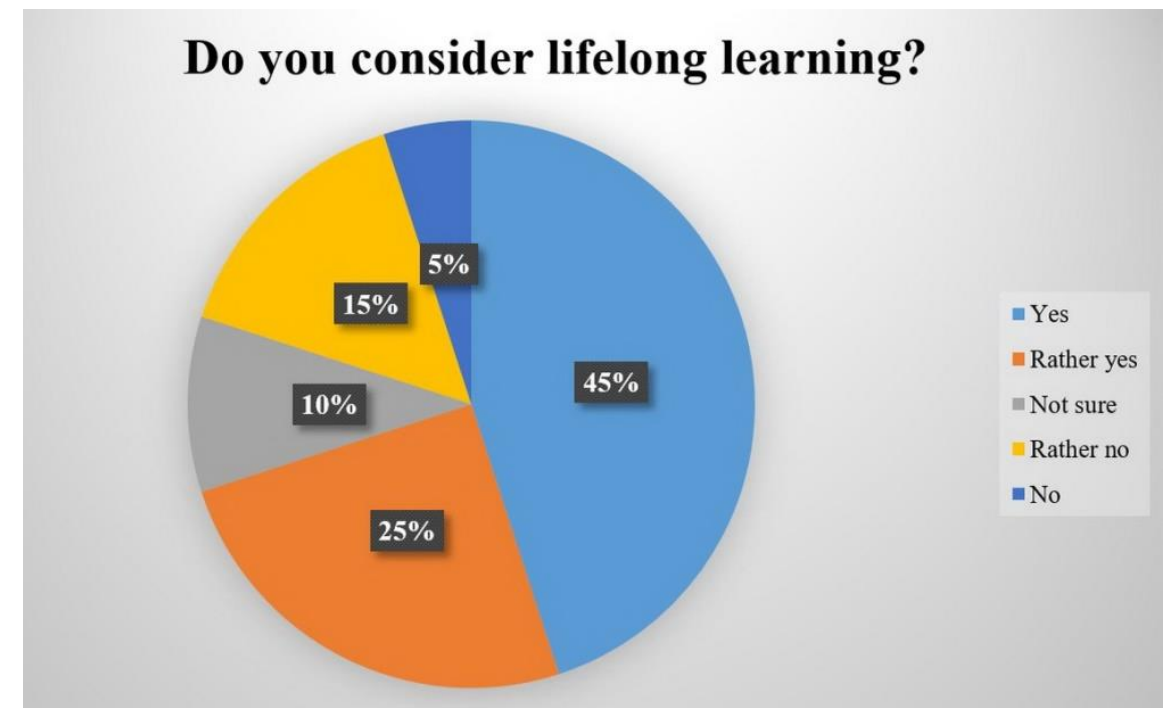

Figure 4. Respondents' answers to the question "Do you consider lifelong learning?".

However, it should be noted that the analysis of the desire and readiness to continue studies among students of different years provided different indicators (Table 1). Thus, a decrease in motivation and interest in lifelong learning with an increase in the year of study from 1 to 4 can be noted. The highest indicators of motivation for lifelong learning were observed among 1st-year students who have just started their studies at a higher educational institution (85\%). In parallel, they were characterized by a decrease in the course of the learning process and the transition to the next year of study. Consequently, not all of the 2-nd year students retained a desire to continue their studies (54\%), which makes it possible to describe the level of motivation as average. Lower indicators of motivation were characteristic of students of the $3 \mathrm{rd}(43 \%)$ and 4 th $(35 \%)$ study years.

Table 1. Data on research participants' motivation before the experimental training.

\begin{tabular}{ccc}
\hline Year of study & Motivation level & Quantitative indicators \\
\hline 1 & High & $85 \%$ \\
2 & Average & $54 \%$ \\
3 & Low & $43 \%$ \\
4 & Low & $35 \%$ \\
\hline
\end{tabular}

In order to analyze the motivation of students for lifelong learning, the question "What is your motivation to continue learning?" was asked (Figure 5). The most frequent answers were "selfdevelopment" (32\%), "improvement of professionalism" (27\%), "quality of education" (21\%). The answers of average frequency were "prestige of the future profession" (8\%), "university" (8\%). Less frequent responses, each occurring once, were combined into the "other" category (4\%). 


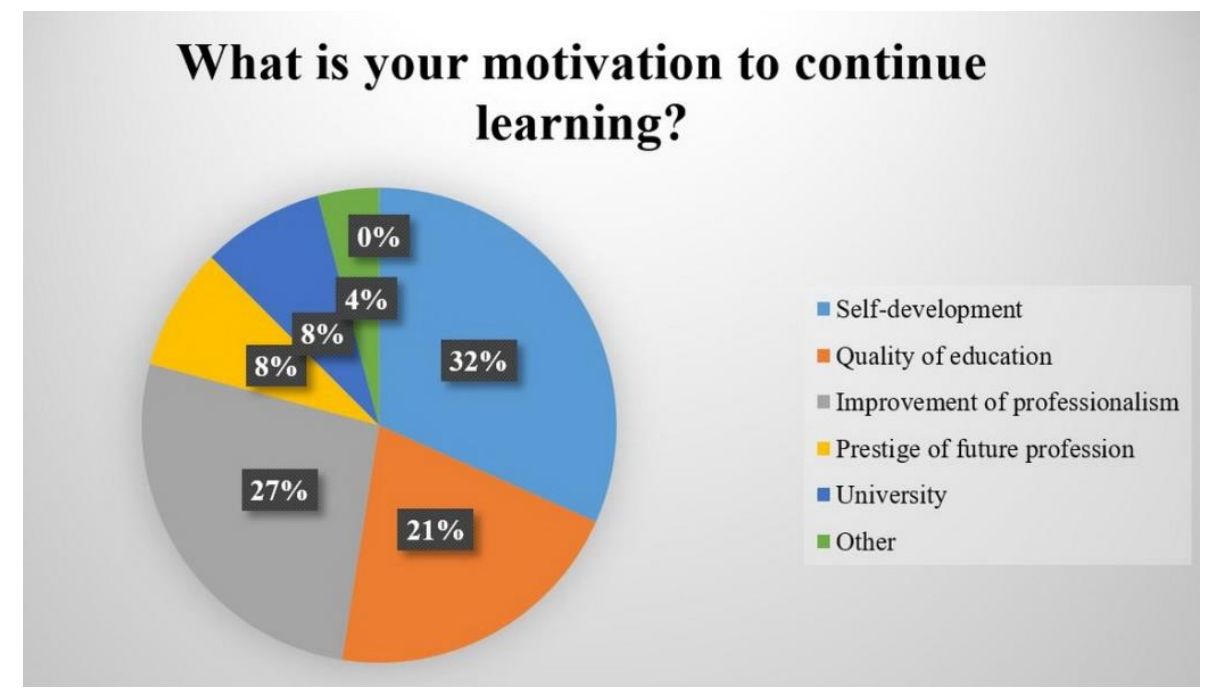

Figure 5. Respondents' answers to the question "What is your motivation to continue learning?" (before the experiment).

The second part of the questions related to modern technologies and the level and features of their use in lifelong learning. Figure 6 shows the answers to the question "Are modern technologies used in your educational institution?" As can be seen, the prevailing part of students (96\%) answered "Yes", while a negative answer was given by only $4 \%$ of them.

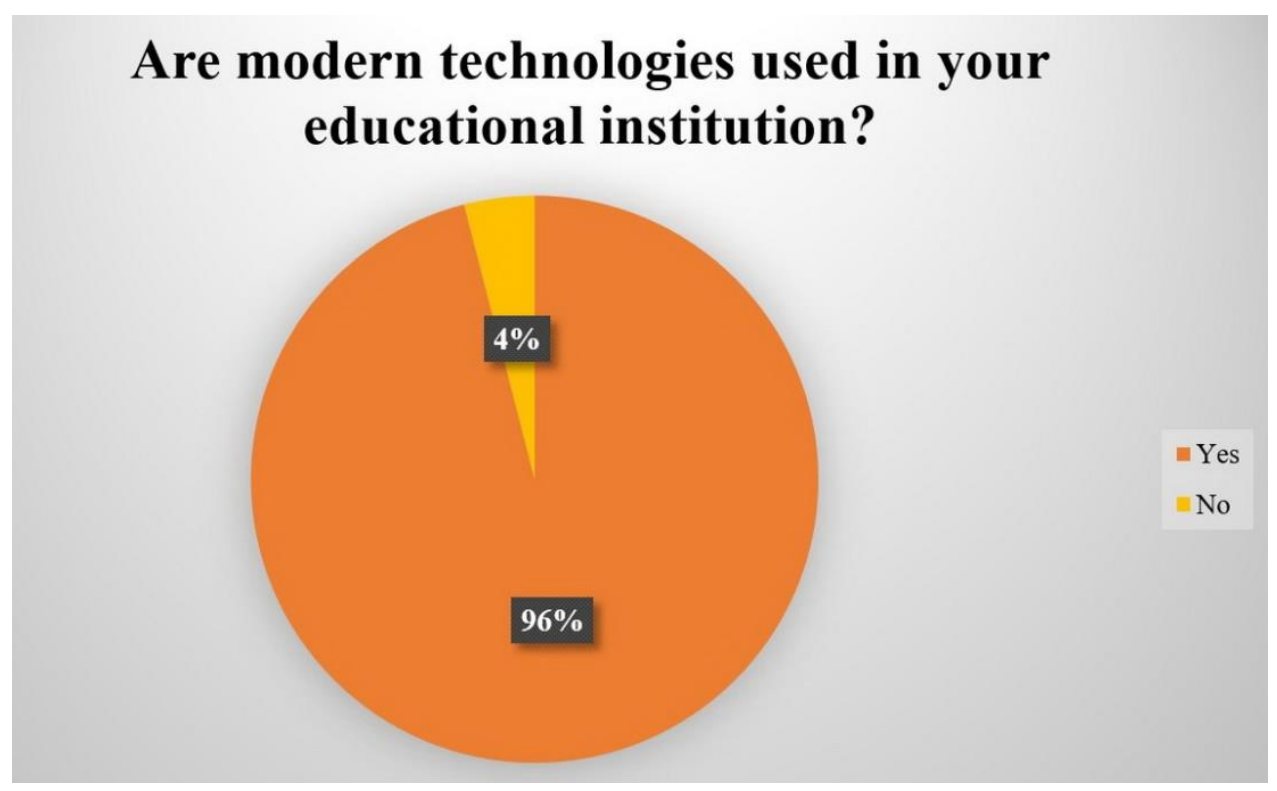

Figure 6. Respondents' answers to the question "Are modern technologies used in your educational institution?"

Figure 7 depicts the answers to the question "What is the effect of modern technologies on the process of lifelong learning?" which made it possible to analyze the opinion of students about the impact of modern technologies on the process of lifelong learning. The collected responses indicate 
that $91 \%$ of research participants assess the impact of modern technologies on the lifelong learning process as positive. However, a small number of students (3\%) are convinced of the negative effect of modern technologies on lifelong learning, and $6 \%$ believe that modern technologies do not affect the lifelong learning process at all.

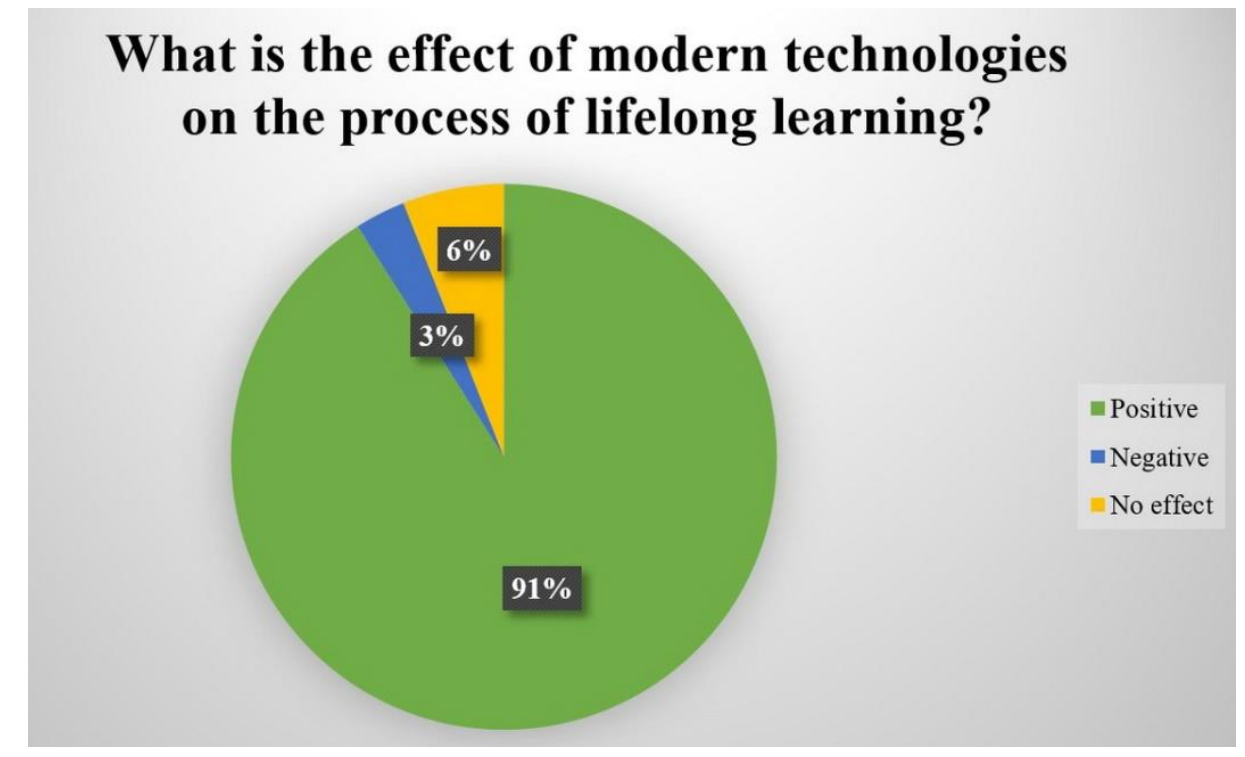

Figure 7. Respondents' answers to the question "What is the effect of modern technologies on the process of lifelong learning?"

lin sum, the survey results point to an increase in demand for lifelong education among students, their willingness to gain such experience, as well as a positive attitude towards modern technologies as one of the means of disseminating and conducting lifelong learning. However, a comparative analysis of the level of motivation of students of different study years to continue learning showed a decrease in motivation indicators in the 3rd and 4th-years, which indicates the need to develop methods for solving the problem.

At the second stage, all the respondents involved were trained according to the developed program aimed at increasing their motivation for lifelong learning (Figure 8). The program was created on the basis of interactive technologies and differed from the traditional training scheme as all classes were focused on practice and development of professional and communication skills, creativity, and critical thinking. It was designed in a manner enabling students to see the learning progress through the development of existing skills and acquisition of new ones, helping them understand that the educational process can be interesting and bring success. 


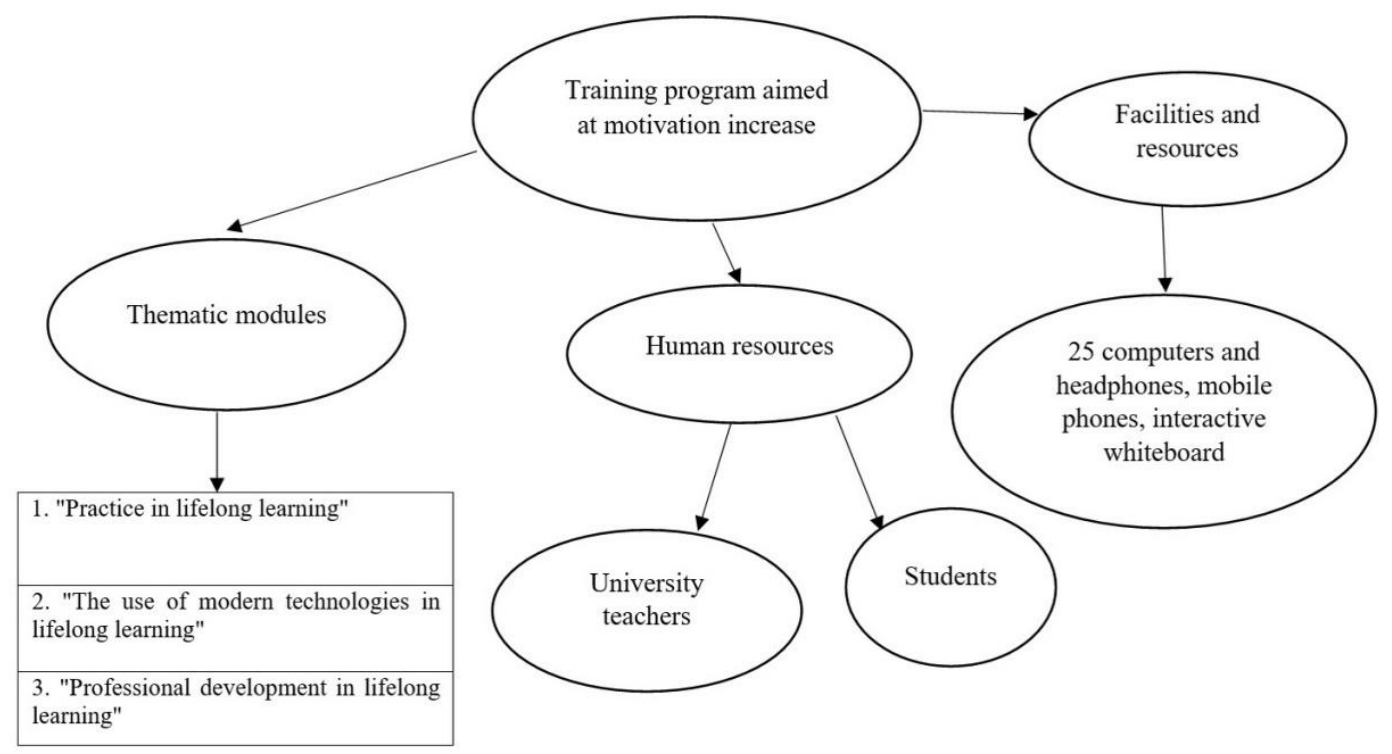

Figure 8. The structure of the training program aimed at increasing student motivation for lifelong learning.

The program consisted of three modules: "Practice in lifelong learning", "The use of modern technologies in lifelong learning", and "Professional development in lifelong learning" divided into separate classes. Its structure implied that each lesson will concentrate on the development of a specific competence or skill (Table 2). Consequently, the first thematic module was devoted to the issue of practice in lifelong learning and was focused on the development of practical communication and creativity skills (solving rhetorical questions, conducting discussions, brainstorming of various communicative situations). For this, students were required to merge into groups. The second thematic module was directed on the use of the most popular and accessible modern technologies in lifelong learning: multimedia presentations, mobile applications, online learning platforms. The interactive whiteboard allowed the teacher to demonstrate the program for working with multimedia presentations, and the students, in turn, worked on their computers. In such a manner, research participants got acquainted with popular educational platforms and the courses presented on them as well as had an opportunity to learn more about mobile applications that can be used in the learning process. Among the various applications related to different spheres, each student could choose what interested them the most. Thus, the mobile application TED provided a number of lectures on different topics in English so students could not only understand a specific topic with the help of lectures but also improve their English. Using the Codeacademy app, study participants got acquainted with online lectures on the basics of programming, as well as completed practical tasks. The A.R.T.S.Y.app was aimed at the general development of students as its focus is set on the field of art. The third thematic block was devoted to professional development in lifelong learning, where students could improve their critical thinking and creativity skills through training courses. Classes of all thematic modules were equipped with all materials and resources needed.

Table 2. The content of the training program aimed at increasing student motivation for lifelong learning.

\begin{tabular}{|c|c|c|c|}
\hline Thematic module & $\begin{array}{c}\text { Thematic module } \\
\text { components }\end{array}$ & Tasks & $\begin{array}{c}\text { Materials and resources } \\
\text { used }\end{array}$ \\
\hline $\begin{array}{l}\text { "Practice in lifelong } \\
\text { learning" }\end{array}$ & $\begin{array}{l}\text { Communicative } \\
\text { competence }\end{array}$ & $\begin{array}{l}\text { Development of practical } \\
\text { communication skills }\end{array}$ & $\begin{array}{c}\text { The course "Psychology of } \\
\text { Communication" on the } \\
\text { Coursera platform }\end{array}$ \\
\hline
\end{tabular}




\begin{tabular}{|c|c|c|c|}
\hline & Creative competence & $\begin{array}{l}\text { Development of practical } \\
\text { skills of creativity in the } \\
\text { learning process }\end{array}$ & $\begin{array}{c}\text { (Coursera, 2021) } \\
\text { Thinking courses by De } \\
\text { Bono (2017), Clegg's } \\
\text { intensive creative thinking } \\
\text { development course } \\
\text { (Clegg, 2004). } \\
\text { A computer with access to } \\
\text { the platform hosting } \\
\text { materials in the form of } \\
\text { video and multimedia } \\
\text { presentations. }\end{array}$ \\
\hline & $\begin{array}{l}\text { Multimedia } \\
\text { presentations }\end{array}$ & $\begin{array}{l}\text { Teaching the skills of } \\
\text { working with multimedia } \\
\text { presentations, the } \\
\text { development of different } \\
\text { types of presentations } \\
\text { on specific topics }\end{array}$ & $\begin{array}{l}\text { Practical } \\
\text { recommendations for } \\
\text { preparing and conducting } \\
\text { presentations ed. by } \\
\text { Kovaleva et al. (2019) }\end{array}$ \\
\hline & Mobile applications & $\begin{array}{l}\text { Formation of the skill of } \\
\text { working with mobile } \\
\text { applications (TED, } \\
\text { Codeacademy, } \\
\text { A.R.T.S.Y.) in the learning } \\
\text { process }\end{array}$ & $\begin{array}{c}\text { A computer with } \\
\text { PowerPoint to work with } \\
\text { multimedia presentations; } \\
\text { interactive whiteboard. }\end{array}$ \\
\hline $\begin{array}{l}\text { technologies in lifelong } \\
\text { learning" }\end{array}$ & & & $\begin{array}{l}\text { A mobile phone with } \\
\text { access to applications on } \\
\text { one of the platforms: }\end{array}$ \\
\hline & $\begin{array}{l}\text { Educational online } \\
\text { platforms }\end{array}$ & $\begin{array}{l}\text { Stimulating motivation } \\
\text { to search for various } \\
\text { courses on online } \\
\text { learning platforms; } \\
\text { teaching the skills of } \\
\text { working with such } \\
\text { platforms }\end{array}$ & $\begin{array}{c}\text { AppStore, Google Play } \\
\text { Market, Amazon Appstore } \\
\text { or Opera Mobile Store, } \\
\text { Online learning platforms } \\
\text { Coursera, LinkedIn } \\
\text { learning, SkillShare. } \\
\text { A computer with access to } \\
\text { online learning platforms } \\
\text { and headphones for } \\
\text { viewing courses; } \\
\text { interactive whiteboard } \\
\text { Online course }\end{array}$ \\
\hline \multirow{2}{*}{$\begin{array}{c}\text { "Professional } \\
\text { development in lifelong } \\
\text { learning" }\end{array}$} & Critical thinking & $\begin{array}{c}\text { Development of critical } \\
\text { thinking }\end{array}$ & $\begin{array}{l}\text { "Fundamentals of Critical } \\
\text { Thinking" on the MDQ } \\
\text { platform (MDQ, 2021) }\end{array}$ \\
\hline & Creativity & $\begin{array}{l}\text { Development of practical } \\
\text { creative thinking skills }\end{array}$ & $\begin{array}{c}\text { A computer with access to } \\
\text { the MDQ platform and } \\
\text { headphones for watching } \\
\text { videos }\end{array}$ \\
\hline
\end{tabular}

The one-month training course consisted of 45-minute classes presupposing the use of modern interactive technologies; students had an opportunity to exchange ideas with teachers and other students. As their focal points were the application of modern interactive technologies, improvement of practical skills, and professional development, appropriate resources, first of all, facilities and 
human resources, were needed for the implementation of the program. The learning process was organized and equipped by the universities participating in the experiment; the classes were conducted by the educators from these universities who provided their written consent to take part in the study. Since the experimental training involved all research participants, for convenience, all students were divided into groups of 25 people. At the same time, they were allowed to change groups and study in different ones every time in order to exchange knowledge and experience. Accordingly, each lesson required 25 workplaces with the same number of computers, headphones, mobile phones, and an interactive whiteboard. The curriculum was posted on the Patreon platform, where students had to register and subscribe to the curriculum page. Access to the page with the curriculum and educational materials was only open to individuals who took part in the first stage of the experiment, registered on the platform, and subscribed to the page. Apart from the already noted functions, educators could upload various videos, materials, or links to online courses, whereas students could have discussions, talk about their ideas and observations.

The results of the third stage of the experiment and the repeated survey showed the effectiveness of the developed training program as the level of students' motivation increased in each study year (Table 3). Thus, the responses obtained for the question "Do you consider lifelong learning?" indicate a significant increase in motivation in all years of study compared to the indicators of the first survey: high in the 1 st $(95 \%)$ and 2 nd (74\%) study years and average in the 3rd (55\%) and 4th (53\%) study years.

Table 3. Data on research participants' motivation after the experimental training.

\begin{tabular}{ccc}
\hline Year of study & Motivation level & Quantitative indicators \\
\hline 1 & High & $95 \%$ \\
2 & High & $74 \%$ \\
3 & Average & $55 \%$ \\
4 & Average & $53 \%$ \\
\hline
\end{tabular}

It should also be noted that the list of students' motivation factors has expanded (Figure 9). While at the first stage of the experiment, the most frequent answers to the question "What is your motivation to continue learning?" were "self-development", "quality of education", and "improvement of professionalism" at the third stage, the students also gave such answers as "interest in the profession" (25\%), "modern technologies" (30\%), "new ideas" (10\%), and "the possibility of practice" (10\%). However, "self-development" (10\%) and "improvement of professionalism" (15\%) were also popular answers among students. Less frequent responses have been grouped into the "Other" category. 


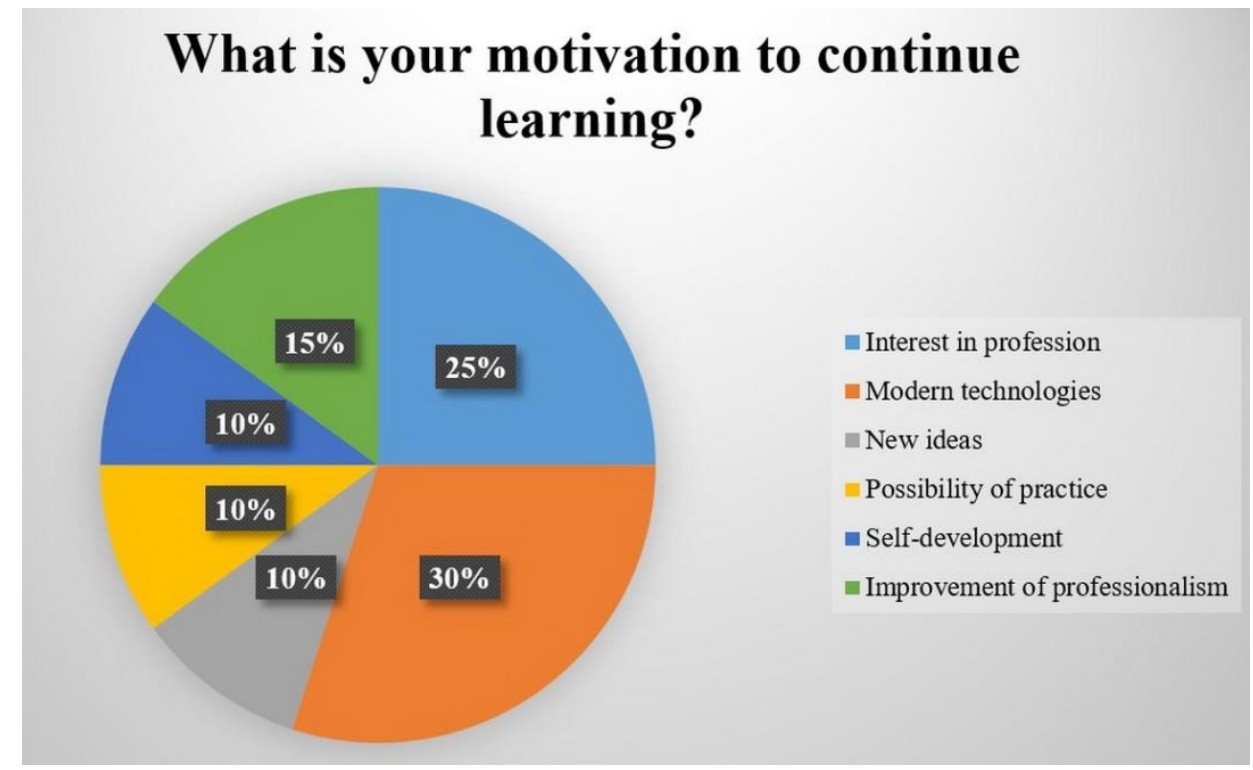

Figure 9. Respondents' answers to the question "What is your motivation to continue learning?" (after the experiment).

The indicators obtained at the third stage of the experiment after the students completed the developed program indicate an increase in their motivation for lifelong learning and an expansion of the number of factors motivating them to continue their studies.

\section{Discussion}

The results of the experiment showed that lifelong learning is popular among the students of Voronezh State University, Novovoronezh Polytechnic College (a branch of the National Research Nuclear University MEPhl (Moscow Engineering Physics Institute)), and Rostov State Transport University. In addition, the participants' responses indicate a high level of the development of lifelong learning in these educational institutions and the desire of students to continue their studies. However, students are characterized by different levels of motivation for lifelong learning depending on their year of study. The outcomes of the conducted investigation also evidence that there is a belief among students that lifelong learning with the use of modern technologies and pedagogical innovations can be described as effective and contributing to the professional development of teachers.

Like a number of other studies (Ignatovich \& Lopukha, 2016), the present work confirms the fact that lifelong learning is becoming increasingly popular. Educational institutions are interested in its dissemination, implementation, and rising students' motivation to continue their studies. The results of the experiment showed that students $(91 \%)$ are confident in the necessity of lifelong learning in the system of modern education; some of them (45\%) even have plans to continue their studies, while others $(25 \%)$ are likely to continue. Compared to the results of other experiments in which institutional or organizational needs were identified as one of the factors of choice to continue learning (Tosaka \& Park, 2017), the findings of this work show various reasons for students' motivation. The most common among them are self-development (32\%), improvement of professionalism (27\%), and quality of education (21\%), while only $8 \%$ of students noted university as a rationale. To some degree, this is in line with an experiment conducted among university students in 
Nigeria, according to which the desire for lifelong learning is explained by motivation, persistence, self-regulation, and curiosity (Chukwuedo et al., 2021). Nevertheless, the main difference is that in the study of Chukwuedo et al. (2021), graduate students and adult learners were motivated by future academic success, while this research implied that no methods of influence on the opinion of respondents were used. Students' motivation for lifelong learning is often associated with achievement as one of the learning objectives (Yilmaz \& Kaygin, 2018). Though, this position matches poorly with the inferences of this work, upholding the view that it is teaching methods used by educators in the learning process that influence students' motivation.

Since lifelong learning is implemented in an educational institution by educators, the issue of its development in an educational institution is unstable and thus relevant. In this context, differences between the results of this study and the findings by other researchers are natural. For instance, the statistical indicator of the level of the development of lifelong learning in educational institutions found within this research (70\%) differs dramatically from the indicators collected in previous experiments (Ignatovich \& Lopukha, 2016).

As concerns the influence of latest technologies and pedagogical innovations on the learning process, in particular lifelong learning, this paper is in good agreement with similar studies standing for the active use of modern technologies in educational institutions (Yu et al., 2018). In the process of lifelong learning, all available methods for obtaining knowledge without any restrictions can be used. This distinguishes lifelong learning from the traditional education based on specific plans and programs that do not always correspond to modern realities and the requirements for education seekers as future employees of different spheres and specialties.

One more fact of a debatable nature is the impact of lifelong learning implemented with the use of modern technologies and pedagogical innovations on the professional development of teachers. The similarity of this research with previous studies is manifested in the conclusions about the effectiveness of the use of modern technologies in the learning process and their strong favorable impact on educators' professionalism (Silver et al., 2019). In turn, the difference is embodied in the described belief regarding lifelong learning as one of the effective ways for instructors' professional development that is able to better students' practical skills and expand pedagogical approaches to education.

A study conducted among students from the Philippines has shown that it is new methods of an innovative nature that have a greater level of effectiveness and impact on student motivation (Sugano \& Mamolo, 2021). Today there are many different technologies that educators from different countries use in teaching. In Uzbekistan, mobile technologies and training programs developed on their basis (Rakhmatov, 2021) are being actively used; in Spain, there are special robots with lifelong learning (Romero et al., 2020). The main trends in lifelong learning in foreign countries are based on innovations and modern technologies, which is explained by the rapid development of science and technology, the processes of globalization, and informatization. In lifelong learning in Russia, the concept of a technology-based approach to education with the use of electronic textbooks, audio recordings, multimedia classrooms, and various laboratories is also being formed (Bekoeva, 2017). However, the trends of lifelong learning with the use of modern technologies in Russia are just beginning to develop if compared to other countries. Covenant University in Nigeria offered an opportunity to develop lifelong learning through developed lessons, while the main approach is the student-centered one based on communication between the instructor and the student, who thus receives not only knowledge in the learning process but also feedback (Worlu et al., 2014). In sum, 
self-education continues to hold the position of one of the most popular lifelong learning trends in many countries (Oprea, 2021). In view of this, the examination of the role of lifelong learning in the education of gifted students and the development of their talents and skills remains relevant (Nacaroğlu et al., 2021).

\section{Conclusions}

The experiment carried out and the conclusions drawn indicate that lifelong learning is gaining enormous popularity in modern education and motivates students to continue their studies. The information space of today and the active development of science and technology creates a need for the use of modern technologies and pedagogical innovations in pedagogical activities, elaboration of new teaching methods and approaches based on the principles of student-centered learning, establishment of cooperation between students, instructors, students and instructors, and combination of theory and practice with an emphasis on the formation of practical skills of creativity, critical and reflective thinking, and communication. The use of modern technologies and pedagogical innovations in lifelong learning was proved to provide additional opportunities for the professional development of educators, as well as improvement of students' practical skills and the learning process on the whole.

The results of the experiment showed an increase in the demand for lifelong learning in the modern learning environment and the active use of modern technologies in this process. The majority of students (91\%) believe that lifelong learning is needed in the modern education system. At the same time, $45 \%$ are going to continue their lifelong learning and $25 \%$ are likely to do so. The analysis of the desire and readiness of students of different study years to continue learning demonstrates nonidentical indicators and a decrease in motivation for lifelong learning depending on the year of study: 1st-years are characterized by a high level of motivation (85\%), 2nd-years have an average level (54\%) while students of the $3 \mathrm{rd}(43 \%)$ and 4 th years lack motivation to learn (35\%). These data confirm a decrease in the level of motivation to continue learning, which is primarily caused by the previous learning experience. The repeated survey conducted after the experimental training under the developed program based on modern technologies finished demonstrated an increase in the motivation of students of each year of study compared to the indicators of the first survey: 1st-year (95\%) and 2 nd-year (74\%) students had a high level of motivation while 3rd- $(55 \%)$ and 4th-years (53\%) had an average level. The most frequent indicators of students' motivation for lifelong learning at the first stage of the experiment were "self-development" (32\%), "improvement of professionalism" (27\%), "quality of education" (21\%), which makes it possible to conclude about the belief that the process of lifelong learning contributes to the improvement of professionalism, provides an opportunity for self-development and improvement of professional and personal skills. However, based on the results of the post-experiment survey, the list of motivation factors expanded and included "interest in the profession" (25\%), "modern technologies" (30\%), "new ideas" (10\%), "the possibility of practice" (10\%). The responses showed that $70 \%$ of students consider lifelong learning in their educational institution well-developed. However, $20 \%$ noted the average level of the development of lifelong learning, and $10 \%$ rated it as low. The majority of students (96\%) confirmed the use of modern technologies in their educational institutions. Overall, the universities, which took part in the study, indicated a high level of the development of lifelong learning.

The practical significance and prospects for further research are seen in the possibility of applying the collected results when carrying out a comparative analysis of lifelong learning features in the context of modern education in other countries. Aside from this, future studies can use the achieved 
Abdalina, L., Bulatova, E., Gosteva, S., Kunakovskaya, L., \& Frolova, O. (2022). Professional development of teachers in the context of the lifelong learning model: The role of modern technologies. World Journal on Educational Technology. 14(1), 117-134. https://doi.org/10.18844/wjet.v14i1.6643

findings to investigate the influence of modern technologies and pedagogical innovations on lifelong learning effectiveness. The developed training program can be taken advantage of by researchers and educational institutions' representatives striving to increase students' motivation for lifelong learning.

\section{Acknowledgements}

Not applicable.

\section{References}

Avidov-Ungara, O., \& Forkosh-Baruch, A. (2018). Professional identity of teacher educators in the digital era in light of demands of pedagogical innovation. Teaching and Teacher Education, 73, 183-191. https://doi.org/10.1016/j.tate.2018.03.017

Bazarova, T., Waganova, W., Dagbaeva, N., Namsaraev, S., \& Fomizkaya, G. (2018). A system of continuing pedagogical education in Russia: Current state and prospects. International Journal of Educational Management, 32(7), 1215-1222. https://doi.org/10.1108/IJEM-11-2017-0326

Bekoeva, M. I. (2017). The main trends in the development of continuing professional education. Modern Scientific Research and Innovation, 4, 721-726.

Berestova, A., Kolosov, S., Tsvetkova, M., \& Grib, E. (2021). Academic motivation as a predictor of the development of critical thinking in students. Journal of Applied Research in Higher Education, in press. https://doi.org/10.1108/JARHE-02-2021-0081

Burkhanova, I. Y., Drandrov, G. L., Ivanova, S. S., Stafeeva, A. V., \& Vorobyov, N. B. (2020). A system of continuing pedagogical education in Russia: Current state and prospects. International Journal of Applied Exercise Physiology, 9(4), 117-124.

Carvalho, A., Teixeira, S. J., Olim, L., Campanella, S. D., \& Costa, T. (2021). Pedagogical innovation in higher education and active learning methodologies - a case study. Education + Training, 63(2), 195-213. https://doi.org/10.1108/ET-05-2020-0141

Christopher, E., Laasch, O., \& Roberts, J. (2017). Pedagogical innovation and paradigm shift in the introduction to management curriculum. Journal of Management Education, 41(6), 787-793. https://doi.org/10.1177/1052562917724553

Chukwuedo, S. O., Mbagwu, F. O., \& Ogbuanya, T. C. (2021). Motivating academic engagement and lifelong learning among vocational and adult education students via self-direction in learning. Learning and Motivation, 74, 101729. https://doi.org/10.1016/j.Imot.2021.101729

Clegg, B. (2004). Intensive course for the development of creative thinking. Astrel.

Coursera. (2021). Psychology of communication. Retrieved from https://ru.coursera.org/lecture/psikhologiyakommunikacii/liektsiia-1-C3pjF

De Bono, E. (2017). Five-day course in thinking. Random House.

De Oliveira Menezes, C. C., Lobato, D. M. N., \& da Silva, V. L. R. (2021). Continuing education and its implications in the teacher pedagogical practices: A possible reflection. Research, Society and Development, 10(3), e24210313224. https://doi.org/10.33448/rsd-v10i3.13224

Gracheva, L. Y., Baghramyan, E. R., Tsygankova, M. N., Dugarova, T. T., \& Sheveleva, N. N. (2020). Models and practices of professional development of teachers in foreign education systems. Education and Science, 22(6), 176-200. https://doi.org/10.17853/1994-5639-2020-6-176-200 
Abdalina, L., Bulatova, E., Gosteva, S., Kunakovskaya, L., \& Frolova, O. (2022). Professional development of teachers in the context of the lifelong learning model: The role of modern technologies. World Journal on Educational Technology. 14(1), 117-134. https://doi.org/10.18844/wjet.v14i1.6643

Ho, Y. Y. C., \& Coady, M. R. (2018). English as a second language nurses in the United States: Culture, communication, and needs for continuing education. Studies in Continuing Education, 40(2), 212-233. https://doi.org/10.1080/0158037X.2018.1460721

Ignatovich, E. V., \& Lopukha, A. O. (2016). Management of the development of lifelong learning at the university: The experience of Petrozavodsk State University. University Management: Practice and Analysis, 5(99), 80-94.

Ilieva-Trichkova, P., \& Boyadjieva, P. (2020). Young people's agency over continuing education in situations of early job insecurity: From enabling to stumbling, Studies in Continuing Education, 42(3), 279-297. https://doi.org/10.1080/0158037X.2019.1615424

Kalz, M. (2014). Lifelong learning and its support with new technologies. In International encyclopedia of the social \& behavioral sciences (pp. 93-99). Pergamon. https://doi.org/10.1016/B978-0-08-0970868.92006-3

Keating, K. (2020). The mindset of a lifelong learner. Chief Learning Officer. Retrieved from https://www.chieflearningofficer.com/2020/05/26/the-mindset-of-a-lifelong-learner/

Khudoykulov, K. D., Parmanov, A. E., \& Aidarov, E. B. (2019). Application of modern pedagogical and innovative technologies in education - standards. European Journal of Research and Reflection in Educational Sciences, 7(12), 1201-1208.

Kimmons, R. (2018). Lifelong learning. In A. Ottenbreit-Leftwich, \& R. Kimmons (Eds.), The K-12 educational technology handbook (Chapter 1.3). EdTech Books.

Kovaleva, M. A., Rutkovsky, A. L., Bolotaeva, I. I., \& Zarochentsev, V. M. (2019). Practical recommendations for making and giving presentations. World of Science.

Mardiana, D., \& Supriyatno, T. (2020). The effectiveness of pedagogical innovation of Islamic education learning (PAl) during Covid-19: A case study of senior high school in Malang-East Java. Advances in Social Science, Education and Humanities Research, 529, 477-482.

MDQ. (2021). Fundamentals of critical thinking. Retrieved from https://mdq.kz/ru/education/online/onlaynkurs-osnovy-kriticheskogo-myshleniya/

Nacaroğlu, O., Kızkapan, O., \& Bozdağ, T. (2021). Investigation of lifelong learning Tendencies and self-regulatory learning perceptions of gifted students. Education and Science, 46(205), 113-135.

Nagovitsyn, R. S., Bartosh, D. K., Ratsimor, A. Y., \& Neverova, N. V. (2019). Modernization of regional continuing pedagogical education in the "School-College-Institute". European Journal of Contemporary Education, $8(1), 144-156$.

Oprea, I. M. (2021). Self-education and lifelong learning. International E-Journal of Advances in Social Sciences, 7(19), 142-145. https://doi.org/10.18769/ijasos.877846.

Rakhmatov, D. (2021). Mobile technologies in the higher education system. Mental Enlightenment ScientificMethodological Journal, 2, 182-196. https://www.doi.org/10.51348/tziuj2021S217

Romero, A., Bellas, F., Becerra, J. A., \& Duro, R. J. (2020). Motivation as a tool for designing lifelong learning robots. Integrated Computer-Aided Engineering, 27(4), 353-372. https://www.doi.org/10.3233/ICA200633

Safari, M., \& Noori, B. (2019). The educational system challenges from the perspective of modern technologies. Journal of Social Sciences, 7(3), 400-407. https://doi.org/10.4236/jss.2019.73033

Salakhova, E. Z., \& Shamsitdinova, M. G. (2020). Advanced pedogogical technologies in education in the 21-st $\begin{array}{lllll}\text { century. ISJ Theoretical \& Applied Science, 5(85), 743-746. } & \text {. }\end{array}$ https://doi.org/10.15863/TAS.2020.05.85.135 
Abdalina, L., Bulatova, E., Gosteva, S., Kunakovskaya, L., \& Frolova, O. (2022). Professional development of teachers in the context of the lifelong learning model: The role of modern technologies. World Journal on Educational Technology. 14(1), 117-134. https://doi.org/10.18844/wjet.v14i1.6643

Shoaxmedova, N., \& Mannanova, S. (2020). Innovative technologies as an aspect of development modern higher education. International Journal of Discourse on Innovation, Integration and Education, 1(4), 85-88.

Silver, R. E., Kogut, G., \& Huynh, T. C. D. (2019). Learning “new” instructional strategies: Pedagogical innovation, teacher professional development, understanding and concerns. Journal of Teacher Education, 70(5), 552-566. https://doi.org/10.1177/0022487119844712

Sugano, S. G. C., \& Mamolo, L. A. (2021). The effects of teaching methodologies on students' attitude and motivation: A meta-analysis. International Journal of Instruction, 14(3), 827-846. https://doi.org/10.29333/iji.2021.14348a

Jălu, Ş. (2019). Implications of modern digital technologies in higher education. Advances in Economics, Business and Management Research, 105, 554-557.

Tosaka, Y., \& Park, J. R. (2017). Continuing education in new standards and technologies for the organization of data and information: A report on the cataloging and metadata professional development survey. Library Resources \& Technical Services, 62(1), 4-15. https://doi.org/10.5860//rts.62n1.4

Vasilyeva, O., Aleeva, Y., Kolesova, S., \& Sigitova, L. (2019). Formation of students' positive motivation to continuing pedagogical education. Advances in Social Science, Education and Humanities Research, 396, 29-33.

Walder, A. M. (2017). Pedagogical innovation in Canadian higher education: Professors' perspectives on its effects on teaching and learning. Studies in Educational Evaluation, 54, 71-82. https://doi.org/10.1016/j.stueduc.2016.11.001

Weitze, C. L. (2017). Designing pedagogical innovation for collaborating teacher teams. Journal of Education for Teaching, 43(3), 361-373. https://doi.org/10.1080/02607476.2017.1319511

Worlu, R. E. K., Atayero, A. A. A., Tuesday, O. S., \& Olaolu, A. L. (2014). Emerging trends in lifelong learning: The Covenant university perspective. In Proceedings of EDULEARN14 Conference 7th-9th July 2014, Barcelona, Spain (pp. 2837-3846).

Yakubova, M. Y. (2021). The modern pedagogical technologies use. Web of Scientist: International Scientific Research Journal, 2(5), 811-816. https://doi.org/10.17605/OSF.IO/ZEMFJ

Yilmaz, E., \& Kaygin, H. (2018). The relation between lifelong learning tendency and achievement motivation. Journal of Education and Training Studies, 6(3a), 1-7.

Yu, K., Gong, R., Jiang, C., Hu, S., Sun, L., \& Luo, Y. Z. (2018). A study on the effect of continuing education with digital technology on professional growth and job satisfaction of librarians. EURASIA Journal of Mathematics, Science and Technology Education, 14(7), 3285-3292. https://doi.org/10.29333/ejmste/91247

Zanina, L. V., Miroshnichenko, A. V., \& Radchenko, O. A. (2019). Continuing pedagogical education in the conditions of digitalization: The risks of alternative society. In $V$ International Forum on Teacher Education (pp. 813-818). https://doi.org/10.3897/ap.1.e0772 